\title{
HOW DO I SEE MYSELF? WHAT DO I WANT TO BECOME? A STUDY ON ENGLISH AS AN ADDITIONAL LANGUAGE TEACHERS' IDENTITY RECONSTRUCTION
}

\author{
COMO EU ME VEJO? O QUE EU QUERO ME TORNAR? \\ UM ESTUDO SOBRE A RECONSTRUÇÃO DE IDENTIDADES \\ DE PROFESSORES DE INGLEES COMO LÍNGUA ADICIONAL
}

\section{Didiê Ana Ceni Denardi* Glória Gil}

\begin{abstract}
This text aims at presenting a piece of qualitative research that investigated the process by which some English as Additional Language (EAL) teachers were involved in (re) constructing their professional identity. Based on socio-interactionist perspectives, the study focuses on investigating some written and oral texts produced by a group of EAL teachers in southwest Paraná to see what these texts reveal concerning their professional identity. In relation to data generation and analysis, this study draws on data from three English workshops of an Extension Program which occurred from March 2012 to June 2013. In those workshops, concepts and ideas related to teachers' professional identity and subjectivity, teacher's social role in public schools, as well as teaching practices were widely discussed. Six in-service teachers attended the workshops regularly and produced oral and written texts of different genres, such as oral discussions and written autobiographies and reports. Some of those texts were, then, selected and analysed. Results show that a) the participant-teachers' identities seem to be fragmented and a life-long process; b) teachers see themselves in constant change and in professional development due to the changes in relation to the EAL teacher's role in public schools and to the EAL status in the world; $\mathrm{c}$ ) the EAL teachers' life trajectories, including social positions (in family, school, work, and in other different social contexts), are essential in the construction of their professional and academic identities.
\end{abstract}

Keyboards: EAL public school teachers; professional identity; oral and written texts.

\section{RESUMO}

Este texto tem por objetivo apresentar uma pesquisa qualitativa que investigou o processo pelo qual alguns professores de língua inglesa foram envolvidos na (re)construção de suas identidades profissionais. Baseando-se em perspectivas sociointeracionistas, o estudo foca na investigação de textos orais e escritos produzidos por um grupo de professores de inglês do sudoeste do Paraná para ver o quê os textos revelam com relação à identidade profissional

\footnotetext{
* UTFPR, Pato Branco (PR), Brasil. didiedenardi@gmail.com; UFSC, Florianópolis (SC), Brasil. gloriagil@gmail.com
} 
desses professores. Em relação à geração de dados e análise, o estudo utiliza dados de três oficinas de um Programa de Extensão que ocorreram de março de 2012 a junho de 2013. Nas oficinas, conceitos e ideias relacionadas à identidade profissional e subjetividade, o papel social do professor em escolas públicas, como também práticas de ensino foram amplamente discutidas. Seis professores em serviço participaram das oficinas regularmente e produziram textos orais e escritos pertencentes a diferentes gêneros, tais como discussões orais e autobiografias e relatos escritos. Alguns desses textos foram, então, selecionados e analisados. Os resultados mostram que a) as identidades dos professores participantes parecem ser fragmentadas e relacionadas ao processo de vida desses professores; b) os professores veem-se em constante mudança e desenvolvimento profissional devido às mudanças em relação ao papel do professor de inglês da escola pública e ao status da língua inglesa no mundo contemporâneo; c) as trajetórias de vida dos professores, incluindo posições sociais (na família, escola, trabalho, e em outros diferentes contextos), são essenciais na construção de suas identidades acadêmicas e profissionais.

Palavras-chave: professores de Inglês como língua adicional; identidade profissional; textos orais e escritos.

Gnōthi seauton/nosce te ipsum/know thyself (Socrates)

\section{INITIAL REMARKS}

Since ancient times, the concept of identity has been crucial for the understanding of human consciousness and development. The Greek Philosopher Socrates (469-399 B.C), for example, used to advise Greek citizens to "know thyself"1 as a form of making them reflect on their self-knowledge and self-control. In fact, knowledge of the self can be seen as the basis for more holistic knowledge about human beings in the world.

This study focuses on investigating written and oral texts produced by a group of EAL teachers in southwest Paraná to see what the texts reveal concerning the teachers' professional identity. For that, some written and oral texts produced by EAL teachers, from a University Extension Program in Southwest Paraná were taken for analysis. In other words, this study tried to investigate some English as a Foreign Language (EAL) public school teachers' texts in which the teachers' reflections might shed some light on their personal, academic and professional experiences.

Thus, in order to investigate such object of study, this research adopts, as theoretical point of departure, some of the studies on teachers' identity carried

1 Gnōtbi seauton in Greek, nosce te ipsum in Latin, know thyself in Old English. 
out in the national and international field, as well as, on EAL teaching or general teaching (JOHNSON, FREEMAN, 2001, BEIJAARD et al., 2004, VARGHESE et al., 2005, TSUI , 2007, CAMARGO; RAMOS, 2008, ECKERT-HOFF, 2009, JOHNSON; GOLOMBEK, 2011, KANNO; STUART, 2011; SCOZ, 2011, to cite just a few). Therefore, this study aims to have an interdisciplinary and critical view of the object of study, and, in this way, to contribute to the field of the English as a foreign language teacher education (EALTE).

\section{IDENTITY: DIFFERENT (AND RELATED) PERSPECTIVES}

Hall (1996/2007) socio-historically discusses the concept of identity or identities and distinguishes three different cultural conceptions of the subject, namely: a) the enlightenment subject; b) the sociological subject; and c) the postmodern subject.

The first cultural conception, the enlightenment subject, revolves around the idea that a human being can be seen as a self-centered subject constituted by reasoning, consciousness and action, with an 'inner core' which emerges from the subject's birth and goes on in a continuum during his/her development. According to Hall $(1996 / 2007$, p. 597), "the essential center of the self was the person's identity" and thus, identity is fixed and the subject is autonomous.

The second conception related the complexity of the modern world to the sociological subject, since it admits that "the inner core of the subject" (HALL, $1996 / 2007$, p. 597) was not only the self, but that the subject is also formed/ developed by means of social interaction. In other words, the second conception, which is close to the Vygostkian perspective of human development (VYGOSTSKY, 1978), is an interactive conception, in which identity is constructed by the interaction between the self and the society, that is, one's identity is formed not by a single identity but by different ones and in different moments and places. From this perspective, identity is seen more as a process influenced and transformed by means of the cultural worlds the subject is inserted in and the identities these worlds offer. Nevertheless, the subject still maintains the essence or "the real me" (HALL, 1996/2007, p. 597).

In the third conception, the post-modern subject is one who does not have an essential or permanent identity. Identity is continuously re-formulated or transformed in relation to the forms and roles one is represented or addressed to in the cultural systems that surround him/her. 
According to Hall (1996/2007, p. 598),

The subject assumes different identities in different times, identities which are not unified around a coherent "self". Within us are contradictory identities, pulling in different directions, so that in such our identifications continuously being shifted about.

Hall (1996/2007) concludes that there is not a complete, secure and coherent identity. A similar idea is proposed by Escoteguy (2001) who, based on Hall, suggests that "identity is a permanent search, is in constant construction, establishes relations with present and past, has history and, because of this, it can not be fixed, determined in one point forever, it implies movement ${ }^{\prime \prime 2}$ (p. 142) [our translation $\left.{ }^{3}\right]$

In the same line of thought, Oliveira Mendes (2011) explains that identity (or subjectivity ${ }^{4}$ ), can be seen as a link between the discourses and practices in which we are inserted as social subjects. Furthermore, identity is constructed in social interactions by means of language/dialogue and practices in which the sense of otherness is always present. In the same vain, Bakhtin (1986) asserts that the subject's sense of otherness is crucial for his/her own consciousness of the self and it is by means of the understanding of the other that the subject can comprehend the form he/she thinks or acts and compare his/her thoughts, beliefs and actions to the others. Bakhtin's idea also implicitly suggests that identity/subjectivity is socially and historically constructed.

However, Bakhtin assumes that "creative comprebension does not -renounce itself its own place in time, its own culture; and it forgets nothing" (1986, p. 7, italics from the original text). Therefore, the understanding/sense of the otherness does not overcome/exceed the self. Conversely, it contributes to its construction since it is provoked by dialogue in different social interactions which can also be transformed into discursive social practices.

Every essence of the other's utterance appreciative apprehension, everything that can be ideologically meaningful has its expression in the inner discourse. The one who apprehends

2 “... a identidade é uma busca permanente, está em constante construção, trava relações com o presente e com o passado, tem história e, por isso mesmo, não pode ser fixa, determinada num ponto para sempre, implica movimento" (ESCOTEGUY, 2001).

3 As some references of this study are written in Brazilian Portuguese, whereas English is the language of the present work, quotations originally written in Portuguese were translated into English. They are identified as [our translation], and the language, as well as, lexical and grammatical choices are of our responsibility. Quotations in their original Portuguese versions can be found in the footnotes.

4 "Identity" and "subjectivity" are used interchangeably along the text.

5 The term "other", here can be understood as another person, as another culture or as the other-I. 
the other's utterance is not a deaf subject, without word, but, conversely, a subject full of inner words. All his mental activity, what can be called "perceptive background" gets him by means of the inner discourse and it is in this way that the link with discourse apprehension in the exterior operates. Word goes to word. It is in the inner discourse that the apprehension of the utterance turns effective, that is the speaker's active orientation (BAKHTIN, 1995/2010, p. 153-4, our translation and italics) ${ }^{6}$.

Dialogism, thus, is another force in the construction of identity/subjectivity. It is by means of utterances that speech communication takes place (BAKHTIN, 1986) and, consequently, utterances are the main fabric of human interaction and foster development (VYGOSTKY, 1978), and of identity construction. Any utterance presupposes a speaker and a listener, that is, any utterance is a response to another one, so it presupposes the presence of other. According to Bakhtin (1986, p. 68) the active role of the other, here represented by the listener, in the process of speech communication cannot be neglected since

...when the listener perceives and understands the meaning (the language meaning) of speech, he simultaneously takes an active, responsive attitude toward it. He either agrees or disagrees with it (completely or partially), augments it, applies it, prepares for its execution, and so on. And the listener adopts this responsive attitude for the entire duration on the process of listening and understanding, from the very beginning - sometimes literally from the speaker's first word. Any understanding of live speech, a live utterance, is inherently responsive, although the degree of this activity varies extremely. Any understanding is imbued with response and necessarily elicits in one form or another: the listener becomes the speaker.

This kind of thought, that is "the listener becomes the speaker" presupposes the active role of the listener since the speaker does not expect a passive understanding, "rather he expects response, agreement, sympathy, objection, execution and so forth" (BAHKTIN, 1986, p. 68) from the part of the listener(s). And, besides, the speaker is also seen by himself as a respondent, since he considers "the existence of preceding utterances-his own and others- which his given utterance enters into one kind of relation or another (...). Any utterance is a link in a very complexly organized chain of other utterances" (BAKHTIN, 1986, p. 69).

6 "Toda a essência da apreensão apreciativa da enunciação de outrem, tudo o que pode ser ideologicamente significativo tem sua expressão no discurso interior. Aquele que apreende a enunciação de outrem não é ser mudo, privado de palavra, mas ao contrário um ser cheio de palavras interiores. Toda a sua atividade mental, o que se pode chamar de "fundo perceptivo", é mediatizado para ele pelo discurso interior e é por aí que se opera a junção com o discurso apreendido no exterior. A palavra vai à palavra. É no quadro do discurso interior que se efetua a apreensão da enunciação, isto é a orientação ativa do falante" (BAKHTIN, 1995/2010, p. 153-4). 


\section{THE PROCESS OF EAL TEACHERS' IDENTITY (RE)CONSTRUCTION}

Most of teachers' conceptions from different disciplines view teachers as intellectual subjects and not as socially constituted human beings. Thus, teachers' personal and professional identities seem to have, many times, been omitted or taken for granted and this, in turn, can be the reason why several projects, which have had the aim of changing and restructuring the way the teaching and learning processes develop, have failed.

Therefore, it is important to observe that teachers are "subjects who produce meanings in their learning and teaching processes, in which social and affective conditions, their thoughts and emotions are integrated ${ }^{7 \prime \prime}$ (SCOZ, 2011, p. 48, our translation). It is also important to take into account that the whole teaching and learning process (and not just the product) in the pre- and in-service teachers' lives should be taken into consideration, including also teachers' own experiences as learners. This way, it can be possible to understand how teachers view themselves as thoughtful and affective subjects, as suggested by Scoz' (2011) words.

\footnotetext{
Taking into consideration the meanings teachers produce in their learning and teaching processes, we can also have access to the ways they situate themselves as thoughtful subjects, as well as to the emotions produced in different learning and teaching situations in different moments and places of their lives ${ }^{8}$ (p. 49, our translation).
}

Thus, taking into consideration the affective aspects of teachers' lives, a post-modern conception of teachers' identity, as discussed in the above section, is retaken. It is possible to realize that subjects - EAL teachers in our case constituted themselves, in the society/community they live and act, in relation to the others. As already hinted at, an identity does not exist in itself, but it is (re) constructed in the relation to the other, and each one of us, has, then, not only one identity, but, contradictory identities which are continuously displaced (ECKERTT-HOFF, 2009).

In view of this, it is possible to realize that one of the main forces of traditional education which is standardization could, in many cases, have resulted in teachers' uniqueness suppression within the school professional framing. Scoz

7 "... sujeitos que vão produzindo sentidos em seus processos de aprender e de ensinar, nos quais se integram suas condições sociais e afetivas, seus pensamentos e emoções" (SCOZ, 2011, p. 48).

8 "Considerando-se os sentidos que os professores produzem em seus processos de aprender e de ensinar, também podemos ter acesso à maneira como eles se situam como sujeitos pensantes, bem como às emoções produzidas em diversas situações de ensino e aprendizagem em diferentes momentos e espaços de suas vidas." (SCOZ, 2011, p. 49). 
(2011, our translation) explains that "uniqueness elimination ends making teachers and students to be perceived as standard elements", and thus, "the teacher does not identify his/her thinking capacity, limiting his/her teaching actions and transforming possibilities ${ }^{10 \prime}$. Thereby, as suggested by Eckert-Hoff (2009, p. 138), it is by means of a process of teacher decentralizing identity that when he/she talks (or writes) about himself/herself, the teacher may have a special view about what is there in the teacher's education game. The triggering of this process may allow the possibility to (re)think and (re)direct EALTE, by means of questioning the tendency to subject homogenization. Hence, the non-stable boundaries of an identity can provoke some displacement, changing the way of thinking of the inservice subject-teacher.

Therefore, there is a need for EAL teachers' personal and professional selfconfrontation since the reflective moment provoked by meaning production can lead teachers to overcome alienation from the school daily life (SCOZ, 2011). In sum, it is important to motivate this practice among teachers, since

there is an urgent need to overcome dichotomy and prejudices related to affective references in teacher education. In the learning and teaching processes, teachers involve themselves with their pupils or students, with students' difficulties and with their own difficulties, that is, with the relations and with the affective requests that permeate these relations. Denying this affective condition would [...] turn back to any possibility of teachers' changing actions ${ }^{11}$ (SCOZ, 2011, p. 50, author's emphasis, our translation).

Specifically, since the 90 's, the EALTE field has grown and several studies about teachers' professional identity have been carried out in different parts of the world and in Brasi $1^{12}$. Some of those studies have been reviewed by Beijaard, Meijer and Verloop's (2004). Using internet as a means of collecting data, the authors reviewed literature from the period 1988-2000, because "this was the period that

9 "a eliminação da singularização acaba fazendo com que professores e alunos sejam percebidos como elementos padronizados" (SCOZ, 2011, p. 51)

10 "o professor não reconhece sua capacidade pensante, limitando suas ações docentes e suas possibilidades de transformação" (SCOZ, 2011, p. 51).

$11^{\prime \prime}$... há urgência na superação das dicotomias e dos preconceitos quanto às referências ao afetivo na formação de professores. Nos processos de aprender e de ensinar, os professores envolvem-se com seus alunos ou com seus ensinantes, com as dificuldades dos alunos e com suas próprias dificuldades, enfim, com as relações e com as solicitações afetivas que permeiam essas relações. Negar esse quadro afetivo significaria [...] virar as costas para qualquer possibilidade de transformação das ações docentes" (SCOZ, 2011, p. 50, grifo da autora).

12 Although this study is written in American English, following Greggio (2009), the name of our country is written in Brazilian Portuguese, so as to keep our Brazilian identity. In the same way, Brazilian names and titles are written in Portuguese to keep their originality. 
teacher professional identity emerged as a research area" (BEIJAARD et al. 2004, p. 108). The authors collected 25 studies and, out of these, 22 were analyzed in terms of a) purpose; b) definition of professional identity; c) concepts related to this definition $;$ d) methodology; and e) major findings. The studies were then divided in 3 categories of studies focusing on: a) teachers' professional identity formation; b) the identification of characteristics of teachers' professional identities; and c) professional identity (re) presented by teachers' stories.

Understanding the concept of teachers' identity, as well as the characteristics of teachers' professional identities is central to this work. The results of Beijaard et al. (2004) on these topics revealed that "the concept of professional identity was defined differently or not defined at all" (p. 107). Based on this finding, it can be said that it is difficult to have a fixed definition on the concept of professional identity. However, the authors said that "four essential features of teachers' professional identity could be derived from the studies" (p. 107). Briefly stating, the characteristics related to professional identity can be synthesized as a) a lifelong learning process, therefore not a fixed paradigm, but always in a dynamic process of construction; $b$ ) a constructed relation between the members of a community of practice (the school context). Teachers have their own values and ways of behave and think, however they have to shape these values and practices accordingly to the limits of the context, and then develop their own teaching culture; c) a set of subidentities, more or less harmonized that are built by means of different relationships and in different contexts the teachers live and act. Some of them may be linked and seen as a core of teachers' professional identity, while others are peripheral. "The more central a sub-identity is, the more costly it is to change or lose that identity" (p. 122); and d) an specific kind of agency "the teachers can exercise, depending on the goals they pursue and the sources available for reaching their goals" (p.123).

To sum up this point and, yet according to Beijaard et al. (2004), teachers' professional identity does not refer just to the answer to the question "Who am I at this moment?", but "Who do I want to become?" (p. 122), that corresponds to "the way they explain and justify things in relation to other people and contexts" (p. 123).

A similar review was carried out by Camargo and Ramos (2008) in Brasil. Taking Beijaard, Meijer and Verloop's (2004) study as a model, the authors reviewed studies related to professional identity of EAL teachers in Brasil. The researchers collected data from the internet, searching for the words 'identity' or 'professional identity of English teacher' in their titles. They could find 6 works ( 2 journal articles and 4 master theses) from 1997 to 2006. 
Concerning the concept of professional identity and characteristics of professional identity, that are the aspects we are interest in this review of literature, the authors' conclude that in Brasil,

The English teacher's identity is permeated by uncertainties, insecurities and conflicts, that teaching courses contribute to this, and that this identity is, at the same time, constructed and imposed by society, and built and corroborated by the English teacher himself/herself (CAMARGO; RAMOS, 2008, p. 194 ${ }^{13}$, our translation).

Therefore, teachers' identity (re)constructions can be seen as process of negotiation of ideas, concepts, meaning or information between the self and the other(s), namely, a process of self-confrontation. Thus, like teacher development, teachers' professional identity can be understood as a phenomenon that lasts a long life term, which constitutes and is constituted by lived experiences and intrapersonal and interpersonal exchanges. However, what is stated by Camargo and Ramos (2008) is that, in Brasil, educational institutions and society as a whole have been contributing negatively to EAL teachers' clashes and doubts about their professional identity, and that this deserves from the teachers educators and universities special attention in order to transform and empower teachers' thoughts and attitudes regarding themselves, thus contributing to their identity reconstruction.

In relation to the ways teachers can have access to their own representations of professional identity - what teachers think about themselves - and so that to make them think about their own process of self-development and professional identity, i.e., self-confrontation, social interaction seems to be crucial. In other words, by means of collective discussions and projects, in which reflections on identity/ subjectivity and pedagogical practice occur, positive changes/transformation in teachers' lives, in school and community can be provoked.

Another form to have access of individuals' identity construction can be by means of the stories they tell about themselves, that is from their life storynarratives or story structures (BRUNER, 1996). These story structures or narratives are culturally bound (BELL, 2002), since individuals construct their own personal narratives based on the conventionalized cultural models provided by the communities they belong to, "which allow them to understand who they are and

13 "...a identidade do professor de inglês está permeada por incertezas, inseguranças e conflitos, que os cursos de formação contribuem para que seja dessa forma, e que essa identidade é, ao mesmo tempo, construída e imposta pela sociedade, e construída e corroborada pelo próprio professor de inglês" (CAMARGO; RAMOS, 2008, p. 194). 
where they are headed" (PAVLENKO, LANTOLF, 2000, p. 160), hence to make sense of their own and other's everyday actions.

Therefore, influenced by some relevant studies on teachers' identities and how they construct them and also on teachers' reflection (AUTHOR, 1999; GIMENEZ, 1999; 2004; 2005; JOHNSON; FREEMAN, 2001; GREGGIO, 2010; AUTHOR, 2011, to cite just a few), some workshops were offered to public school teachers of southwest Paraná since 2012, as part of a University Extension Program. In the workshops, teachers produced some written and oral texts, such as life-story narratives and classroom discussions, which generated relevant data for investigation.

In the next section, we will present some main methodological procedures used to carry out this work.

\section{METHODOLOGICAL ASPECTS}

As previously stated, the main objective of this qualitative interpretative study (DENZIN ; LINCOLN, 1998) is to investigate how teacher identity reconstruction happened by analyzing some of the written and oral texts produced by some EAL public school teachers.

It is important to say again that due to the complexity of its object of study, this investigation can be situated within an interdisciplinary field. In view of this, some constructs from Sociology (HALL, 1998, OLIVEIRA MENDES, 2011, SOUZA SANTOS, 2011), Psychology (VYGOSTSKY, 1978 and followers), Linguistics (BAKHTIN, 1986, 1995/2010), Applied Linguistics (AUTHOR, 2005; GIMENEZ, 1999; 2005) were used to theoretically guide the research.

The investigation tries to answer the following research questions:

1. What are some common characteristics of the personal and professional identities of the investigated teachers?

2. How do the investigated teachers see themselves as EAL teachers?

3. What do they want to become?

Data was generated from some workshops carried out at the Programa de Extensão Parceria Universidade-Escola, which is a partnership established between Curso de Licenciatura em Letras Português- Inglês of the Universidade Tecnológica Federal do Paraná Campus Pato Branco and Núcleo Regional de Educação de Pato 
Branco/Paraná-Brasil in 2011. Although the partnership was sealed in 2011, the workshops and actions of the university extension program started in March 2012 and have run until now. The main objective of the Program is to contribute to the Portuguese and English teachers' process of teaching and learning improvement, as well as to the improvement of Basic Education in southwest Paraná.

Specifically, this study draws on data from three English workshops of the Program which occurred from March 2012 to June 2013. In those workshops, concepts and ideas related to teachers' professional identity and subjectivity, teacher's social role in public schools, as well as, teaching practices were widely discussed. The workshops were attended by a total of 38 teachers, most of them female teachers in which 7 , out of these 38, participated in 2 workshops and 6 participated in all the 3 ones. In this way data generation and analysis were carried out based on written and oral productions developed by the 6 teachers who attended all the 3 workshops in the extension program. In other words, the reports of school micro and macro contexts, participants' life narratives or autobiographical texts, memories, testimonials, as well as oral and written classroom and methodological reports, teaching beliefs and opinions constitute the corpus of this work. Besides, participant teachers and the classes of English workshops in the Extension Program from March 2012 to April 2013 were observed and some classroom events were recorded and transcribed. Observations were used as secondary data. Oral and written texts from the 6 public school teachers, were, then, selected and analysed by means of content analysis (SPRADLEY, 1995). The oral text was transcribed without using any special transcription conventions and using ordinary written Portuguese conventions, such as punctuation signals.

\section{ANALYSIS AND DISCUSSION}

This section aims to analyze and discuss the data of this study. However, before starting the analysis and discussion, it seems relevant to provide the reader(s) of this article some information related to the context of production of the texts. As already mentioned, participants produced their texts in the workshop classes of an Extension Project and at home. They were told that the objective of the written tasks and discussions was to provoke some reflections about themselves as teachers and about their pedagogical practices and that no ready answers for their doubts would be given or provided, instead, they could get some answers from their collective reflections, discussions and text studies ${ }^{14}$. Besides, there was no 
publication of the texts since they were written or orally produced to the teachers themselves, to the teacher educator and for academic reasons.

The investigated corpus reveals some interesting and intriguing events or life situations the investigated EAL participant-teachers' went through, which were translated in different themes, that are: a) life trajectories; and b) capacities, limitations, desires and expectations, consequently providing representations of themselves as EAL public school teachers.

\subsection{Teachers' life trajectories: some similar characteristics}

As already said and in general terms, participants are public school teachers in southwest Paraná with average of 12 to 18 years of teaching experience. They are all female, the youngest is 32 and the oldest is 46 , all married and the average number of children is 2 . They are from different cities of the southwest region of Paraná: Lúcia and Rosalina live in Clevelândia, Sandra and Iracema in Pato Branco, Maria in Saudades do Iguaçú and Ana ${ }^{15}$ lives in São João, but works in São João and Chopinzinho. All of them are majors in Letters Portuguese and English at Public and Private Universities in the southwest region of Paraná.

From the participant-teachers' autobiographical texts their life trajectories emerge. Their texts make evidence the way they passed from a difficult to a more stable social life condition, as well as, their great effort to become teachers, as can be observed by means of their reports and discursive representations that follow.

- Participant-teachers came from lower middle working class families: (1) My parents worked with my grandparents (...) as farmers with great difficulties. The difficult of my family was because there wasn't work with technological resources (...) but we were never left without assistance (Maria' autobiography) ${ }^{16}$.

(2) My life was not easy. As soon as my mother became pregnant she had to move to another city (...) where I was born (...). The years that followed were not easy to my parents, my father started drinking (alcohol) and became very sick, no longer worked more (...) my mother could no work out because she had a baby, a daughter with six and another with ten, it was me (Iracema's autobiography).

14 This piece of research is part the Program "Formação inicial e contínua de professores de Inglês na região Sudoeste do Paraná" which has the agreement of Plataforma Brasil - Comitê de Ética em Pesquisa (CEP) under the number 303.284 dated June 13th 2013. To know more about the Program read "Integração e formação em Letras Português e Inglês" (AUTHOR $;$ Jacobsen de Oliveira, (2013) on the website of Extramuros Magazine, that is www.extramuros.univasf.edu.br). 15 Ana, Maria, Sandra, Iracema, Lúcia, and Rosalina are participant-teachers' fictional names.

16 Excerpts 1 to 12 are copied and pasted from teachers' texts since their writings also show theirs professional identities. 
- Participant-teachers started working very young:

(3) I helped my mother cleaning the house. At thirteen I started working to help with expenses. Since then I have not stopped working, but I never stopped studying (Iracema' autobiography).

(4) After I graduated High School, I started teaching children in a local public school (Maria’s autobiography).

- Participant-teachers worked in one city and concomitantly attended undergraduate course in another city:

(5) ... 1992, I decided to do Letters course, (...) at CEFET (Pato Branco). In that time I was teacher of children in elementary school (in the city of São João/PR)- (Ana’s autobiography).

(6) I went to study high school in Chopinzinho city because in my city there wasn't high school. After I graduated High School, I started teaching children in a local public school (...). Then in 1999, I started undergraduate English Letters in Palmas/PR (studying there a week a month) (Maria's autobiography).

- Participant-teachers constructed their families concomitantly with their professional studies:

(7) I finished College in 1996 and I married (...) In 1998 I did my specialization course (Ana’s autobiography).

(8) I began studying at University in 1984 (...) In 1986, I got married and we lived in Marechal Candido Rondon for four years (Lúcia’s autobiography).

- Participant-teachers started teaching English at public school:

(9) I graduated in 1999 at "Faculdade de Filosofia, Ciências e Letras de Palmas, but before that I became a teacher. I started teaching English to students from the Public School in Clevelândia in 1998 (Sandra’s autobiography).

(10) ....in 1999, I started undergraduate English Letters in Palmas/PR. While I was studying I started working as an English teacher in public school (Maria's autobiography).

- Participant-teachers taught different levels and had different experiences in schools:

(11) I began to work as a teacher in 1991 in Mato Grosso-ten years (...) as a Portuguese teacher and after this, we came back to live in Toledo again. I began as an English teacher at (Educação de Jovens e Adultos) where I taught four years. In 2006, we came to live in Clevelândia (...). In 2012, I continue teaching in Public School with 40 hours a week as an English teacher (Rosalina's autobiography).

From the excerpts above, it is possible to observe some recurrent words/ expressions which reveal participant-teachers' life trajectories showing important aspects of their subjectivities as individuals (difficulties, life not easy life, studying, 
working, married, etc.) and their social identity as professionals (start teaching, public schools, etc.).

Besides, most of the excerpts (3-11) are written in the first person singular (e.g., I helped my mother, I graduated high school, I started working, I began to work, etc.), that refer to themselves as subject. This shows the empirical voices of the participants and their engagement as agents of their own development and teacher identity construction. Also, the use of verbs in the past (e.g.: helped, graduated, decided, have not stopped working, went, started teaching) and the use of time adverbials and dates (e.g., after, before that, in 1992, then) show the stories participants tell can be understood as true histories.

In other words, participants (as subject of the sentence) tell their histories to their Other-I, the me (object of the sentence) and by reminding the important facts, passages and events that occurred in their lives reflect over their life trajectories. Besides, it can be said that this way participants try to reconstruct their identities as professionals, since they recovered the efforts, which can be translated by Norton Peirce (1995) and Norton's (2000) as "investments" they made to become EAL teachers. As a kind of illustration, Ana's voice is brought here:

(12) The route of my life: I studied very much, however, I believe that people need is always to search what make them happy (...) I am happy when I am searching, reading, studying, exchanging ideas with other people... Then, this person is me: Ana (Ana's autobiography).

\subsection{Teachers' capacities, limitations, desires and expectations}

As already mentioned, different genres of texts, such as classroom reports and teachers' classroom discussion on beliefs about teaching and learning English were collected and analyzed. However, in this paper, the analysis that follows is mainly based on only one oral discussion ${ }^{17}$ about the understandings of the concepts of identity, subjectivity and teacher's practice. This choice was due to participants' spontaneity and enthusiasm during one episode in that discussion. The classroom discussion was based on the readings of some theoretical texts teachers were assigned to read and synthesized as a course task, such as Tavares (2009), Freitas (2009), Soares Martins (2009) and Eckert-Hoff (2009). In general terms, the studied texts deal with the issues of teacher education and teacher's professional identity.

17 Discussion was audio recorded with the permission of the participants, then transcribed for analysis. As the present article is written in English, teachers' excerpts were translated. 
The readings of the already mentioned theoretical texts seem to have triggered the participants' process of thinking about themselves, as seen in the excerpt below.

13-Sandra: ... we analyzed our own discourse by ourselves, didn't we?

14-Lúcia: Sure!

15-Sandra: Yes... It was clear that teachers saw themselves as knowledge center teachers, they had the control of the classroom, but in a conception of repassing knowledge.

16-Lúcia: Transmitter

17-Sandra: Transmitter isn't he/she? Because he/she focused in "I' a lot in discourse, didn't he/she?

18-Teacher-Educator: Did you do this brief analysis, when you were talking in the group this morning?

19-Sandra: Yes! Lúcia ... did the analysis of the involved teachers in the pieces of research and we also ended identifying ourselves.

20-Lúcia: ... realizing in our discourse too. And one of the teachers of the research said how difficult it is. Realizing also in the difficult thing the change, suddenly you, they do the teacher build himself/herself, the attitude of any professional that is life, it is the family. There are several influences, and suddenly break with this paradigm is difficult and it is also difficult in the classroom. You face, you realize that what you have done, eh... not wrong, but that you could do different, you don't get to do the didactic transposition, because it was internalized... 21-Teacher-Educator: Ah!

22-Sandra: Then... it is also is...Everything is a process and you Eh, the teacher made a comment that at home, we, she uses "we", women, didn't we? We kind of manipulate, everything is the center in ourselves. And she also says that we take this to the teaching practice, then even unconscious when we see... she is reproducing this practice of concentrating things.

23-Lúcia: Yes... the teacher said that

24-Sandra: Identity, isn't it?

25-Lúcia: That what... that you should, that they should to monitor the process in the classroom, and when they realized that they didn't do that, they were almost imposing what they wanted, weren't they? Then, they didn't allow the student learn by himself/herself, and grow up, then, there was that... hurry to see the thing finished.

Interestingly, from the data generated on that episode, there was one specific limitation implicit in the participant-teachers' discourse: the teachers seemed to see themselves as controlling teachers in their EAL classes. This was signaled in their discourses by some of the expressions they used, such as "knowledge center teachers", "control of the classroom", "repassing knowledge" and "monitor the process in the classroom".

Also, in the middle of their reflection, specifically in turn 20, Lúcia seems to change her talk to another direction showing another difficulty, when she suggests that "break with this paradigm is difficult (...) in the classroom. (...) and you don't get to do the didactic transposition, because it was internalized....". As seen, it is possible to understand that Lúcia refers to the difficulty she and colleagues have to break with traditional teaching paradigms or patterns and make adequate didactic 
transposition in the classroom, that is, to work with authentic texts that belong to different genres as directed by the teaching official document of Paraná State such as Diretrizes Curriculares Estaduais para Línguas Estrangeiras Modernas (PARANÁ, 2008). According to Lúcia, breaking with traditional paradigms is difficult because it is internalized/ fossilized, maybe. The teacher-educator accepts the point saying "Ah!" (turn 21). However, as the topic she points out goes to another direction, soon Sandra tries to bring it back to the discussion, as can be seen in turns 22 to 25 . Her insistence shows the importance that this topic had for her.

Later on, the topic of EAL teaching-learning approach in public schools is retaken. Sandra, in turn 98, reminds us about Tavares' (2009, p. 55) text ${ }^{18}$, when she tried to explain the reasons that hinder the classroom' possibility of changing to a more democratic approach.

\begin{abstract}
98 Sandra: ... that is that we talked about, that nowadays we know that teaching and learning isn't based only in cognition. '...it implies forgetting the utopian process control, to assume the impossibility of to know and to teach everything, because language is much more that a communicative instrument, it is the own way of subject's constitution and the inclusion in the language universe is its crucial!...teachers there, were discussing their practices and got to the conclusion that they were wanting to take too much control of the process. We do that many times because we learned it in a traditional method. We came from a traditional school ....ah... to us, I believe that we've read about discourse not from a long time, about sense construction, about critical reading, then I think that we, language teachers, in general nowadays, we are... how can I say? ... not in equilibrium. I can't say that we have a constructed identity.
\end{abstract}

As already suggested, Sandra (turn 98) shows understanding that the language teaching-learning approach in the classroom should be less controlled and more democratic, since the process of teaching-learning is not just based on learners' cognition, but also, and mainly, in viewing language as discourse, that is viewing language as a social practice that serves to interpersonal communication and interaction but also as an instrument of subject's constitution and development, as noted by Tavares (2009). Also, Sandra admits that she and her colleagues have been studying/researching on discourse, meaning construction and critical reading not for a long time, and the fact of understanding language not as a system of signs but as a social practice and the migration from a traditional to a discursive perspective of language teaching and learning has brought them many doubts and conflicts which leads her to say: "I can't say we have a constructed... identity". In the last sentences, the participant seems to express, at the same time, the kind of a conflicting clash she (and her colleagues) had, as well as, the desire to construct or

18 Tavares' (2009) text refers to learners' impact in their subjectivities when learning EAL. 
have a defined identity as EAL teachers. In a certain way, Sandra is speaking out her 'post-modern' anxiety about the changing and unstable nature of today's identity.

The participants' (re)construction of identities is also related to an understanding of the status of the EAL nowadays, as well as the EAL teacher's role and objective in Basic Education in Brasil, which is affected by the elements of the socio-cultural dimension such as students, parents and institutions. Let's look at the excerpt below in which the investigated teachers are also discussing one of the reading texts:

\begin{abstract}
74-Sandra: ... (someone) also analyses some students' speech and the representation that they do between texts related to foreign language from (...) prejudice that they have stipulate in reason of these discourses they have had access in their lives. There is a student (...) she has a concept that learning English is to have fluency, in fact. Then they are the discourse of the society that one form or other, she unconsciously stipulates a concept to what is good learning of a foreign language.

75- Lúcia: she also affirms that when you speak a foreign language eh + you are consider as a wise person. That you have more information than other ones, don't you?
\end{abstract}

As seen, the participants are reporting on a text that points out that the students have the pre-established representation that for someone to know English it is necessary to speak the language, and that this representation is strongly influenced by society. Later on, they go on talking about the representations that make it difficult for students to see that the objective of teaching and learning English in regular school is to understand EAL teaching/learning as an instrument for human development, as can be seen in the long sequence below:

115- Maria: when it is said to us that learning eh...Specifically, many times there is some resistance of this, but on the other hand English, in some cases, they present us English as a universal language. Without a foreign language someone can get a good job. English is the most spoken language and so on. Then, how do we, foreign language teachers, behave related to these speeches? That in fact are already...., they are ready sentences already. How do we pose ourselves in relation to this question?

116-Sandra: It isn't much time that I've been working, 14 years, I have a little... Short period, and when I started, I yet ... We were guided by that discourse to educate for the work market, to use English to travel abroad, to read for graduate courses. Then, it is, it would be in thesis easier because the focus is only in the linguistic structure, only in... In learning the language, kind of mechanics still, it would get the objectives...Now, when I say ... a student identifies himself/herself identifies with the language, builds subjectivity, builds identity, oh! It takes so great dimension the teaching of a foreign language that we have to study (...).

117-Ana: to rethink practice.

118-Sandra: To rethink practice every day, that we, although have been studying, we go to the classroom and sometimes we can't transform theory into practice. To know my student, because if I work with affectivity, subjectivity, with identity ... We should have close relationship, then ..in those other questions of.. 
119- Maria: ...that the language teacher has a lot of classes to close his/her schedule, few hours with the student.

120-Ana: Taking into account that those classes there are less students.

121-Sandra: Then it is a...a too great challenge to us, and it is a worry because it is a great responsability to educate subjects and thoughtful students.

122-Rosalina: Critical ones! Because it was very practical, to have a foreign language as a used language. Because it was useful. If I learn to travels, I'll learn to work market. It was directed. Then, with the teacher's involvement was lesser. Then, when we think about this, subjectivity, build an identity on the identity that he/she already has... Building new identities... It is to reconstruct identity that I have. That view of my world centered in my country, focusing in new horizons, as my mother built identity will change as the new on that I am acquiring. And this is conflict, it is crises so... unstructured (laugh) to us teachers. I think that this .... us. And see, how many teachers are searching to read and learn a little more about this new view? I believe not much, don't I? They are already feeling that only that mechanics, useful, it isn't enough.

This long excerpt shows evidences of the kinds of conflicts participantteachers face in trying to understand their new roles as EAL teachers. They first question themselves about how they can act in relation to the common representation that people should learn English in Brasil because it is e a useful instrument for "personal contact with abroad", "job market" and "upward social mobility" (MACHADO; AUTHOR, 2012), as in turn 115 when Maria says : "how do we, foreign language teachers, behave related to these speeches? That in fact they are already...., they are ready sentences. How do we pose ourselves in relation to this question...?". She seems to refer to some functional ideas /sentences that are constantly heard when the question is: Why study English? And, then, they reveal that they feel insecure on how to accomplish their role as EAL teachers in Brasil by contributing to students' development as citizens and human beings. In this regard, Sandra, in turn 116, says: "It takes so great dimension the teaching of a foreign language that we have to study (...).

$(\ldots)^{\prime \prime}$, thus suggesting that they need to go on studying to be able to cope with this dilemma.

Other difficulties/limitations and conflicting thoughts expressed by participants were related to the physical and socio-subjective conditions of the school and language classes. Some of the aspects participants discussed are related to:

- Overworking: "....that the language teacher has a lot of classes to close his/ her schedule, few hours with the student" (turn 119-Maria);

- Overcrowded and heterogeneous classes, social inclusion and time limitations: 
205-Rosalina: And many times he/she faces ... organized, with the best material, well, many other different things, when preparing the classes in what you have to prepare different activities to inclusive students, when we have learning limitations, as dyslexics, and so on, but some students' indiscipline who are older to be in some classes. They don't know how to read, and are there, sixth year. Then, many times time is, how often do you prepare, you don't get and... got? You come so optimist, you get there something goes wrong and your class that would be a show...

- Course-book: In Brasil ${ }^{19}$, the federal government provides coursebooks, however teachers have difficulties to make the adequate didactic transposition.

206-Ana: And even in relation to the didactic book, as Sandra said that is was to follow the didactic book. I think it is impossible, because there are some activities there that you can't do, can't you? There are things that you can't do. Books. Books no, sorry! Large texts.

207-Sandra: There are things, that are over their ages.

208- Ana: This is a question on the time. It is a question that you have to have the criticism to analyze each of the proposal activities, because it's not easy.

- Students' motivation: students seem to be demotivated to study EAL, since they do not feel they are users of it or even belong to a multilingual world, in which English prevails.

114-Rosalina: How to teach another language, one, it is possible, isn't it? Put yourself near the language (inaudible), this affectivity with the student, with the learner. And she mentions that we have to pose ourselves this way, don't we? I am also from this English language world, and not only from Portuguese language world. I am also part of that, she said. It is, "I say..." I assume what I am". Then from the moment you assume, you build that affection, you have that desire to learn.

In sum, from the analysis above, it is possible to get some of the participant teachers' main criticisms regarding how they actually see themselves, in Column 1 in Table 1 below, compared with they want to be, in Column 2, that is, their implied desires and expectations derived from the criticisms.

19 PNLD (Plano Nacional do Livro Didático) is a Program that analyzes, selects and distributes course-books to all public schools in Brasil. 
Table 1: Participants' views about their school limitations, desires and expectations

\begin{tabular}{|l|l|}
\hline COLUMN 1 & COLUMN 2 \\
PARTICIPANT-TEACHERS' CRITICISMS/ & $\begin{array}{l}\text { PARTICIPANT-TEACHERS' } \\
\text { DESIRES AND EXPECTATIONS/POSITIVE } \\
\text { NEGATIVE REPRESENTATIONS RELATED } \\
\text { TO THEIR ACTUAL IDENTIES }\end{array}$ \\
\hline $\begin{array}{l}\text { Teachers see themselves as the center and in } \\
\text { CRITICISMS }\end{array}$ & $\begin{array}{l}\text { Teachers want to be a classroom mediator } \\
\text { guiding autonomous students }\end{array}$ \\
\hline $\begin{array}{l}\text { Teachers are in crisis/ in conflict incapable to } \\
\text { break old paradigms }\end{array}$ & $\begin{array}{l}\text { Teachers want to go searching for improving } \\
\text { knowledge and practice; }\end{array}$ \\
\hline $\begin{array}{l}\text { In spite of being aware of their social roles, } \\
\text { the teachers have some limitations to behave } \\
\text { accordingly; }\end{array}$ & $\begin{array}{l}\text { Teachers want better work conditions in the } \\
\text { schools: less students per class, adequate and } \\
\text { motivating materials and instruments to teach, } \\
\text { more pedagogical support; time to prepare the } \\
\text { classes, students motivated, as well as, to have a } \\
\text { continuous educational program. }\end{array}$ \\
\hline $\begin{array}{l}\text { Teachers do not see themselves as privileged } \\
\text { part of a wide system }\end{array}$ & $\begin{array}{l}\text { Teachers want education be considered as a social } \\
\text { instrument for human and social development }\end{array}$ \\
\hline $\begin{array}{l}\text { Teachers do not have enough knowledge of the } \\
\text { things in the world and about language }\end{array}$ & $\begin{array}{l}\text { Teachers want to be able to make criticisms on } \\
\text { books, activities and so on. }\end{array}$ \\
\hline $\begin{array}{l}\text { Teachers reproduce theoretical discourse on the } \\
\text { role of the language as subject constitution, from } \\
\text { texts they have read. }\end{array}$ & $\begin{array}{l}\text { Teachers want to be critical, reflexive } \\
\text { professionals, able to apply in the classroom } \\
\text { what theories require, that is: view language } \\
\text { as a social practice that serves to interpersonal } \\
\text { communication and interaction but also as } \\
\text { an instrument of subject's constitution and } \\
\text { development. }\end{array}$ \\
\hline
\end{tabular}

In order to conclude this section, it is important to show one of participantteachers own conclusion about their identities.

241-Sandra: I think we see ourselves as incomplete subjects. We know about our difficulties, limitations and at the same time challenged to search for a new way, that we are still by means of the study finding (....) also working with a language that is not fixed, with identity, subjectivity and that is a building process. Then we have left a fixed, we can say, fixed, comfortable to a challenge of what will be, or what will come to be. It is in constant change, now we see ourselves as frightened (laugh), afraid, but also hee...

242- Someone: Curious.

243-Sandra: Curious.

244-Teacher Educator: Brave

245-Sandra: Brave

246-Iracema: In some moments insecure, am I right? Am I not right? ... in the form of teaching, in the question of the importance of the language. 
Because nowadays it is not (...)it is an international language, but... because we are open to new knowledge and pass this type of information, this different view of the globalized world that we didn't have this opportunity to have the experience with this globalized world that our students have nowadays.

As seen from the participant-teachers' voices, they see themselves in constant change, and professionals who are becoming aware of fluidity of identity.

\section{SOME FINAL REMARKS}

To conclude, the results of this study on teacher identity show that: a) the participant-teachers' identities seem to be fragmented and constructed throughout a life-long process; b) the teachers see themselves in constant change and in professional development due to the changes in relation to the EAL teacher's role in public schools and to the EAL status in the contemporary world ${ }_{i}$ ) the EAL teachers' life trajectories, including social positions (in family, school, work, and in other different social contexts), are essential in the construction their professional and academic identities.

Furthermore, the findings of this empirical investigation have shown that the experience of working with written tasks (such as autobiographies) and oral discussions of theoretical texts resulted for the participants-teachers in an fruitful opportunity since they could reflect upon their own way of learning and teaching, and be able to develop critical view of their roles (public) and identities (subjectivities) as EAL teachers and teaching. Thus, working with these genres can promote EAL teachers' personal and professional self-confrontation and reflection, that is, a process of teacher decentralizing identity (ECKERT-HOFF, 2009, p.1 38), which may, in turn, help them to overcome the alienation (SCOZ, 2011) favored by traditional education.

As a piece of academic research, this study seems to be relevant to the education area and, especially to EALTE in Brasil, because it has tried to tackle the needs, conflicts and expectations of a group of teachers from Southeast Paraná Brazil, who are interested in developing their pedagogical practices and progress academically, and aim to (re)construct their professional identity.

This study also has tried to denounce how teachers see the needs and difficulties they have to engage in, take collective decisions for and act in favor of the public school system by conceiving themselves as educational professionals able to understand the educational policies, the organization of the pedagogical 
work, the social context in which the school is inserted and the renewed social role of EAL classes in Brasil.

\section{REFERENCES}

BAKHTIN, M.M. (1986). The problem of genre speech. In: Bakhtin, M.M. Speech genres and other late essays. University of Texas Press, Austin, pp. 60-102.

BAKHTIN, M.M. (1995/2010). Marxismo e Filosofia da Linguagem: problemas fundamentais do Método Sociológico na ciência da Linguagem. São Paulo: Editora HUCITEC.

BEIJAARD, Di MEIJER, P. C.; VERLOOP, N.(2004). Reconsidering research on teacher's professional identity. Teaching and teacher education. Elsevier, n. 20, pp. 107-128.

BELL, J. S. (2002). Narrative Inquiry: more than just telling stories. Tesol Quarterly, 36 (2), pp. 207-212.

BRUNER, J. (1996). The culture of education. Cambridge (MA): Harvard University Press.

CAMARGO, G. Q.; RAMOS, S. M. (2008). Reconsiderando pesquisas sobre a identidade profissional do professor de língua inglesa no contexto brasileiro. Maringá/PR: Acta Sci.Bioal.Sci. v.30, no. 4, pp.189-196.

AUTHOR (2011). Representações de professores de Inglês sobre uma experiência de ensino e aprendizagem de escrita mediada pelo procedimento de sequência didática. In: Cristovão, V.L.L. (Org.). Atividade docente e desenvolvimento. Campinas, SP: Pontes Editores, pp. 155-170.

AUTHOR; JACOBSEN DE OLIVEIRA, A. (2013). Integração em Letras Português e Inglês. Revista Extramuros UNIVASF, v.1, n.1, pp. 144-154.

DENZIN, N ; LINCOLN, Y. (1998). Collecting and interpreting qualitative materials. Thousand Oaks: Sage Publications.

ECKERT-HOFF, B. M. (2009). A escritura de si na formação do professor. In: Bertoldo, E. S. (Org.). Ensino e aprendizagem de línguas e formação do professor: perspectivas discursivas. São Carlos: Clara Luz, pp. 135-152.

ESCOTEGUY, A.C. (2001). Cartografia dos estudos culturais: uma versão latino-americana. Belo Horizonte: Autêntica.

FREITAS, V. A. B. (2009). Aspectos da subjetividade brasileira no contato/confronto com uma língua estrangeira. In: Bertoldo, E. S. (Org.). Ensino e aprendizagem de línguas e formação do professor: perspectivas discursivas. São Carlos: Clara Luz, pp. 71-88.

FREITAS, V. A. B. (2005). Mapeando os estudos de formação de professores de línguas no Brasil. In: Freire, M., Abrahão, M. H. \& Barcelos, A. M. (Orgs.), Lingüística aplicada e contemporaneidade. São Paulo: Pontes/ALAB, pp. 173-182.

GIMENEZ, T. (1999). Reflective teaching and teacher education: contribution for teacher training. Linguagem \& Educação. v.2,n.2, pp. 129-143. 
GIMENEZ, T. (2004). Tornando-se professores de inglês: experiências de formação inicial em curso de Letras. In: Vieira-Abraão M.H. (Org.). Práticas de língua estrangeira: experiências e reflexões. Campinas: Pontes, pp. 153-169.

GIMENEZ, T. (2005). Currículo e identidade profissional nos cursos de letras-Inglês. In: Tomitch L. M. B., et al. (Orgs.). A interculturalidade do ensino de inglês. Florianópolis/SC - ARES, pp. 331-344.

GREGGIO, S. (2009). The concept of the teacher as a reflexive professional and its use in English language teacher education in Brasil. Tese de Doutorado em Letras Inglês. Universidade Federal de Santa Catarina, Florianópolis.

GREGGIO, S. ;AUTHOR.(2010). O conceito de professor reflexivo na formação de professores de inglês no Brasil. In: Barros, S. M. de; ASSIS-PETERSON, A. A. Formação crítica de professores de línguas: desejos e possibilidades. São Carlos: Pedro e João Editores, pp. 55-68.

HALL, S. (1996/2007). Modernity: in an introduction to modern society. USA: Blackwell Publishing, pp. 596-634.

JOHNSON, K.; FREEMAN, D. (2001). Teacher training in second language teacher education: a socially situated perspective. Revista Brasileira de Linguística Aplicada. v.1,n.11,pp. 53-69.

JOHNSON, K. E. ; GOLOMBECK, P.R. (2011). The transformative power of narrative in second language teacher education. Tesol Quarterly. v. 45, n. 3, pp. 486- 909.

KANNO, Y.; STUART, C. (2011). Learning to become a second language teacher: Identities in-practice. The Modern Language Journal. pp. 236-252.

MACHADO, E. H. S; AUTHOR. (2012). As representações sociais de estudantes de ensino fundamental público sobre o ensino de língua inglesa. Uniletras. v.34, n.2, pp. 139-156. Accessed in: http://www.revistas2.uepg.br/index.php/uniletras. Online: March 19th, 2014

NORTON PEIRCE, B.(1995). Social identity, investment, and language learning. Tesol Quartely, v. 29 n. 1, pp. 9-31.

NORTON, B. (2000). Identity and language learning: gender, ethnicity and educational change. Harlow, England; Longman/Pearson Education Limited.

OLIVEIRA MENDES, J. M. (2011). O desafio das identidades. In: Santos, B.S. (Org.). A globalização e as ciências sociais. São Paulo: Cortez, $4^{a}$. ed. pp. 503-540.

PARANÁ (2008). Diretrizes Curriculares da Educação Básica do Paraná. Língua Estrangeira. Secretaria de Educação do Estado do Paraná. Superintendência de Educação. Departamento de Ensino Fundamental.

PAVLENKO, A. ; LANTOLF, J. (2000). Second language learning as participation and the (re)construction of selves. In: Lantolf, J. (Ed.). Sociocultural theory and second language learning. Oxford: OUP.

SCOZ, B. J. (2011). Identidade e subjetividade de professores: sentidos do aprender e do ensinar. Petrópolis, RJ: Vozes. 
SOARES MARTINS, A.C. (2009). A emergência de discursos conflitantes na prática de ensino de língua inglesa. In: Bertoldo, E. S. (Org.). Ensino e aprendizagem de línguas e formação do professor: perspectivas discursivas. São Carlos: Clara Luz, pp. 107-134.

SOUZA SANTOS, B. de (2011). A Globalização e as Ciências Sociais (Org.). $4^{\text {a }}$ ed.São Paulo: Cortez. (1995).

SPRADLEY, J. P. (1980). Participant Observation. Florida, USA: Harcourt Brace Jovanovich College Publishers.

TAVARES, C. N. V. (2009). Deslocamentos identitários no encontro com uma língua estrangeira. In: Bertoldo, E. S. (Org.). Ensino e aprendizagem de línguas e formação do professor: perspectivas discursivas. São Carlos: Clara Luz, pp. 51-70.

TSUI, A. B. M. (2007). Complexities of identity formation: a narrative inquiry of an EAL teacher. Tesol Quartely, v. 41, n. 4, pp. 657-680.

VARGHESE, M. et al. (2005). Theorizing language teacher identity; three perspectives and beyond. Journal of language, identity, and education, v. 4, n. 1, pp. 21-44.

VYGOTSKY, S. (1978). Mind in society: the development of higher psychological processes. Cambridge, MA: Harvard University Press.

Recebido: 07/07/2014

Aceito: $17 / 05 / 015$ 